\title{
PANDANGAN PENGARANG ATAS BURUH MIGRAN INDONESIA DALAM NOVEL SUMAYYAH KARYA NIZAR ABADZAH
}

\author{
Nur Hidayah ${ }^{1,2}$ \\ ${ }^{1}$ Fakukltas Studi Islam Universitas Nahdhatul Ulama Yogyakarta \\ ²Email: hidayahaq@unu-jogja.ac.id
}

\begin{abstract}
Indonesian Migrant Workers are Indonesian workers who work abroad. They must leave Indonesia at a productive age, by leaving various social problems to bear the burden of solving family economic problems and providing foreign exchange for the country. These foreign exchange heroes in the country where they work are seen as tools to get work done, and not as human beings who need privacy, protection, respect and other human needs. This view has caused many problems, both psychological and social problems that have not been resolved until now, especially for migrant workers who work in the domestic sector, as happened to Marruni, a character of migrant worker in the novel of Sumayyah by NizarAbadzah. Abadzah is seen as a character who comes from the country that uses migrant workers' services. This study is needed to understand the root problems that have been faced by Indonesian Workers who working in the Middle East. This study aims to find out author's world view Marruni, the character of Indonesian Migrant Worker in the Novel of Sumayyah by using the theory of genetic structuralism.
\end{abstract}

Keyword: Indonesian Migrant Worker. Novel of Sumayyah, genetic structuralism.

$$
\begin{aligned}
& \text { ملخص } \\
& \text { بوصف كوفم العمال في خارج إندونيسيا، كان العمال المهاجرون الإندونيسيون لا بد لمم من مغادرة وطنهم فن } \\
& \text { العمر المنتج مع حمل كثير من مشكلات اجتماعية من أجل تحمل مسئولية اقتصادية لدى الأسرة، مع أفم أسهموا }
\end{aligned}
$$

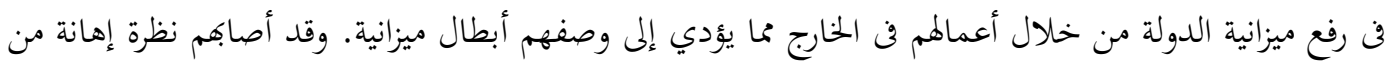

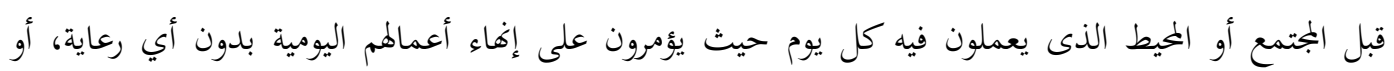

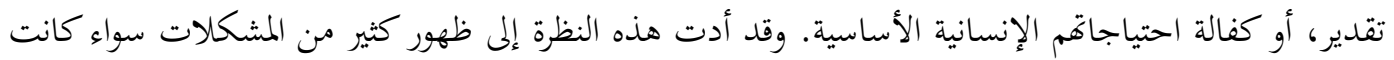

$$
\begin{aligned}
& \text { نفسية أم اجتماعية وهي مشكلات لا تزل قائمة غير محللة حتى الآن خاصة مشكلات تواجه العمات العمال في نطاق }
\end{aligned}
$$

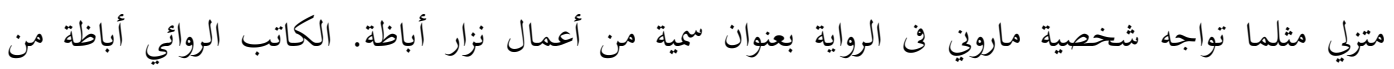

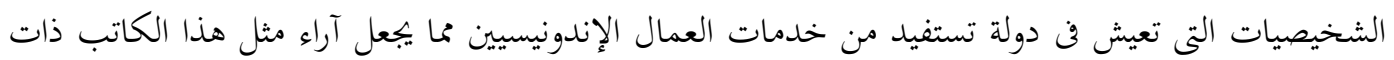

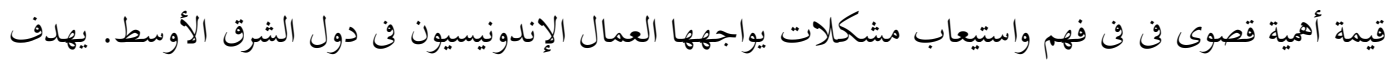

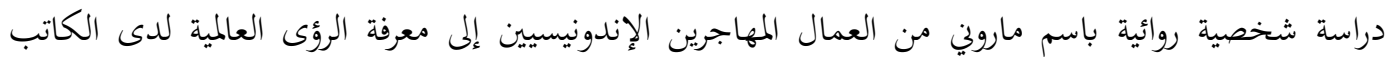

$$
\begin{aligned}
& \text { الروائي نزار أباظة مستخدما نظرية التركيبية الوراثية. } \\
& \text { الكلمات المفتاحية: العمال المهاجرون الإندونيسيون، رواية سمية، نظرية التركيبية الوراثية. }
\end{aligned}
$$




\section{A. Pendahuluan}

Menjadi buruh migran yang bekerja di luar negeri bukanlah pilihan terutama apabila harus bekerja di wilayah domestik yang rentan dengan masalah. Hal itu krena para buruh migran tersebut harus tinggal bersama sang majikan dalam satu rumah, dengan jam kerja yang tidak pasti, tanpa hari libur dan privasi, serta tidak memiliki akses untuk berinteraksi dengan sesama warga negara Indonesia yang berada di negara di mana dia bekerja. Meskipun penuh dengan resiko, namun banyak perempuan Indonesia yang memutuskan untuk bekerja dan di luar negeri bersama orang asing. Berbagai alasan menjadi latar belakang mereka mengambil resiko tersebut, seperti gaji yang besar. Novitasari (2017:) mengklasifikasikan latar belakang tersebut dalam beberapa kategorei, antara lain ekonomi, seperti sedikitnya lapangan pekerjaan, gaya hidup, selisih gaji yang tinggi dan non ekonomi seperti keinginan untuk melakukan ibadah Haji. Sehingga Timur Tengah menjadi negara tujuan favorit para buruh migran muslim untuk bekerja, dan salah satu negara yang membuat perjanjian kerja sama dengan pemerintah Indonesia adalah Syria. Pemerintah Syria cukup ketat dalam menerima tenaga kerja asing dan hanya bekerja sama dengan 6 negara saja, yaitu Indonesia, Bangladesh, Srilanka, Nepal, Vietnam dan Philipina (www.mofa.gov.sy). Meski demikian menurut bbc.com, banyak buruh migran Indonesia yang bekerja di Syria illegal, dan keberadaan mereka tidak dapat diakses Kedutaan Besar Indonesia untuk Syria.

Pada tanggal 8 agustus 2009, koran paltoday.ps. memberitakan pembunuhan pembantu Indonesia yang membunuh majikannya di Syria. Pembantu Indonesia ini mengaku membalas dendam karena perlakuan kasar majikannya. Pada tanggal 25 oktober 2009 koran ww.dp-news.com memberitakan kisah Aminah, pembantu Indonesia yang mendapatkan siksaan majikannya yang merupakan seorang artis besar Syria. Kedua pemberitaan tersebut menjadi berita nasional yang mendapatkan perhatian serius dari masyarakat Syria pada tahun 2009. Seakan hendak menjawab pemberitaan tersebut, pada tahun yang sama Abadzah menerbitkan sebuah novel yang berjudul Sumayyah dan diterbitkan oleh penerbit Darul-Fikr. Novel yang menceritakan konflik psikologis tiga tokoh perempuan, Sumayyah, Ibunya dan Marruni ini menarik untuk dikaji karena mengungkapkan tokoh karakter Buruh Migran Indonesia yang bekerja di Syria. Sejauh yang dapat ditemukan, baru novel berbahasa Arab Sumayyah yang mengungkapkan kisah buruh migran Indonesia yang bekerja di Timur Tengah. Kajian yang dapat ditelusuri pun masih dari sudut pandang insider, yaitu para peneliti Indonesia. Novel ini dirasa berbeda karena sudut pandangnya berasal dari outsider, yaitu negara pengguna jasa Buruh Migran Indonesia.

Tokoh Marruni dalam novel Sumayyah menjadi objek formal yang dikaji dengan menggunakan pendekatan teori strukturalisme genetik untuk mengetahui pandangan dunia pengarang atas tokoh buruh migran Indonesia yang bekerja di sektor domestik di negara Syria. Banyak masalah yang muncul dalam perjanjian kerja sama antara pemerintah Indonesia dan pemerintah negara tujuan buruh migran, terutama negara-negara Timur Tengah yang masih merugikan para buruh migran Indonesia.

Penelitian ini merupakan penelitian literatur dan bersifat kualitatif dengan menggunakan pendekatan strukturalisme genetik untuk menjawab beberapa pertanyaan, yaitu : (1) Bagaimana pandangan dunia Abadzah sebagai pengarang novel akan profil buruh migran perempuan (BMP) Indonesia dalam novel Sumayyah?; (2) Apa permasalahan yang dihadapi tokoh Marruni sebagai buruh migran Indonesia yang bekerja di Timur Tengah?; dan (3) Apakah ada hubungan antara pandangan dunia pengarang dengan permasalahan yang dihadapi BMP Indonesia yang bekerja di Timur Tengah? 
Berdasarkan hasil pengamatan dari berbagai sumber, belum ditemukan penelitian akan pandangan dunia pengarang atas buruh migran Indonesia dalam novel Sumayyah Karya Nizar Abadzah. Adapun penelitian atas pandangan dunia dengan menggunakan teori strukturalisme genetik sudah banyak dilakukan, seperti disertasi Farhah tahun 2015 yang berjudul Romantisisme Islam, analisis strukturalisme genetik dalam Thauqul Chamamah fil Ilfah wal Ullaf karya Ibnu Chazm Al-Andalusi yang mengungkapkan romantisisme Islam menurut Ibnu Chazm. Pada tahun 2013 Hakim mengkaji pandangan dunia Ali Ahmad Bakatsir dalam Novel Sallamah Al-Qas dengan menggunakan analisis strukturalisme Genetik Lucien Goldmann. Dalam penelitiannya Hakim mengungkapkan pandangan pengarang tentang paham jabariyah yang terqadariahkan sebagai jalan tengah atas keberadaan kedua paham yang saling bertentangan tersebut.

Adapun kajian tentang Buruh Migran Indonesia telah banyak dilakukan, seperti kajian Nasution pada tahun 1998 tentang Mobilitas tenaga kerja Indonesia ke luar negeri dan dampaknya terhadap diri migran di Malaysia. Pada tahun 2002 Soelaiman melakukan kajian tentang Solusi Upaya Perlindungan Tenaga Kerja Indonesia (TKI) di Luar negeri. Dalam penelitiannya ini Soelaiman mengungkapkan penyebab para buruh migran bermigrasi ke luar negeri di antaranya adalah karena ketidaksesuaian jumlah antara lapangan kerja di Indonesia dengan para pencari kerja, yang kemudian justru menjadi berkah bagi para buruh migran ini untuk bekerja di luar negeri. Pada tahun 2012 Sulistiyo dan Wahyuni melakukan kajian tentang dampak Remitan bagi posisi sosial buruh migran perempuan dalam rumah tangga. Para BMP yang sudah melakukan bekerja di luar negeri lebih sering memutuskan untuk kembali bermigrasi karena berbagai hal yang kemudian merubah status sosial mereka dalam rumah tangga maupun di masyarakat. Sehingga menurut Sulistyo dan
Wahyuni, jika pada tahun 1999 angka remitan yang masuk ke Indonesia mencapai US\$ 2 milyar, maka angka ini menembus US\$ 6,6 milyar pada tahun 2008. Akan tetapi sejauh yang dapat diketahui, penelitian-penelitian dari sudut pandang insider ini, baru berupa penelitian yang dilakukan dari sudut pandang penduduk Indonesia, negara yang mengirimkan para buruh migran, belum dari sudut pandang negara pengguna para Buruh Migran. Sehingga penelitian ini dirasa lain, karena dilakukan untuk memahami bagaimana penduduk negara pengguna buruh migran dalam memandang buruh migran Indonesia yang bekerja di negaranya. Penelitian ini dirasa tepat untuk dilakukan sebagai salah satu bahan kajian pemerintah untuk merumuskan pembaharuan kebijakan untuk memeberikan perlindungan lanjutan bagi para buruh migran Indonesia, terutama para perempuan yang bekerja di sektor domestik di negara-negara Timur Tengah.

\section{B. Landasan Teori}

Buruh Migran Indonesia (BMI) dikenal juga dengan istilah Pekerja Migran Indonesia (PMI) dan Tenaga Kerja Indonesia (TKI). Menurut Toyib dalam penelitiannya (2009:45), istilah Buruh Migran Indonesia (BMI) lebih dipilih dari istilah TKI atau PMI karena: (1) buruh migran lebih berkonotasi pada pekerja fisik dengan nilai tawar yang rendah, yang bekerja pada sektor informal dan domestik seperti Pembantu Rumah Tangga, Pekerja Perkebunan, dan lain-lain yang membutuhkan jaminan perlindungan; (2) buruh migran mengandung arti pekerja illegal dengan dokumen tidak lengkap sebagaimana yang ditetapkan oleh hukum negara dan atau kesepakatan internasional; (3) kata buruh migran dipilih oleh konvensi internasional 1990 pasal 5 tentang perlindungan hak pekerja migran dan anggota keluarganya.

Rohmah (2017:124) melihat istilah Buruh Migran Indonesia terdiri atas tiga suku kata, yaitu buruh, migran dan Indonesia. Buruh adalah orang yang 
bekerja agar mendapatkan upah atau imbalan. Adapun migran adalah orang yang berpind dari satu wilayah ke wilayah lain. Nainggolan (2008:43) membagi migrasi buruh ini ke dalam dua kateori, yaitu urbanisasi dan migrasi ke luar negeri. Faktor utama penyebab terjadinya migrasi dari dalam adalah gaji yang rendah, sedikitnya lapangan pekerjaan dan rendahnya akses sosial masyarakat, di samping tawaran gaji yang kompetitif, kepastian akan pekerjaan dan keinginan seseorang untuk meninggalkan negaranya. Globalisasi, pasar bebas dan kemajuan ekonomi sebuah negara menambah tinggi pergerakan tenaga kerja dari satu negara ke negara lain (Wahyudi dalam www.buruhmigran.or.id). Akan tetapi tidak semua orang dapat melakukan migrasi ke luar negeri. Negara-negara yang menganut system Patriarkhi lebih memilih Buruh Perempuan untuk bekerja di sektor domestik, dan permintaan untuk bekerja di sector ini sangat tinggi, sehingga jumlah perempuan yang melakukan migrasi ke luar negeri ini sangat besar, dilihat dari jumlah remitan buruh migran perempuan yang lebih besar dari remitan buruh migran laki-laki (Azmy, 2012:2). Untuk bekerja di sektor publik para buruh migran ini harus berusia 18 hingga 30 tahun. Adapun untuk bekerja di sektor informal seperti menjadi Pembantu Rumah Tangga atau pekerjaanpekerjaan domestik, rentang usianya lebih luas, yaitu antara 21-40 tahun (resmipjtki.com).

Kepergian para BMI ini meninggalkan masalah sosial, seperti daerah yang ditinggalkan oleh para tenaga kerja produktif, perselingkuhan, anakanak yang tumbuh tanpa pendampingan orang tua, untuk menjemput masalahmasalah baru seperti pemerkosaan, perselingkuhan, gaji yang tidak dibayar, sakit, kematian, atau eksekusi mati tanpa pembelaan. Selain permasalahan sosial tersebut, para Buruh Migran juga meghadapi masalah-masalah psikologi seperti rasa kosong karena terisolasi sendiri dalam keluarga asing selama bertahun-tahun, hidup dalam kebudayaan dan bahasa yang tidak mudah baginya, tanpa perlindungan hukum dan support sistem negara tempat di mana dia bekerja (Toyib, 2009:49). Sehingga mereka rentan mendapatkan pelecehan. Meski demikian, sesungguhnya menurut Toyib (2009:47) remitan para Buruh Migran ini memiliki peranan yang sangat besar bagi Indonesia. Akan tetapi perlindungan bagi para buruh migran terutama yang bekerja di sektor domestik masih minim. Undang-Undang yang ada hanya mengatur proses penempatan tenaga kerja, bukan aspek perlindungan dan keselamatan buruh Migran. Menurut Toyib (2009:49), dari 109 pasal dan $16 \mathrm{Bab}$, hanya 8 pasal (pasal 77-84) Peraturan Undang-undang no. 39 tahun 2004 saja yang mengatur perlindungan para Buruh Migran.

Menurut Darmanto, karya sastra tidak diciptakan dari kekosongan, karena diciptakan dengan tujuan tertentu. Sebuah karya sastra adalah media bagi pengarang untuk berbicara tentang kehidupan, baik sebagai realita maupun gagasan dan citacita (Santosa, 2006:1). Sebelum menciptakan sebuah karya, seorang pengarang menjalani tiga tahapan seperti, (1) kecenderungannya dalam menalar dan memberi makna atas kenyataan hidup yang dia hadapi; (2) kecenderungannya untuk konsisten atau tidak konsisten dalam segala hal, untuk kemudian menciptakan bentuk-bentuk struktur budaya tertentu; dan (3) kecenderungannya untuk mengubah dan mengembangkan struktur-struktur yang sudah ada di mana dia menjadi bagian dari struktur itu sendiri (Goldmann dalam Santosa 2006:20).

Teori strukturalisme genetik memandang teks sastra sebagai produk yang dihasilkan dari proses penghayatan masyarakat di mana sebuah karya dilahirkan. Karya ini lahir dari fakta kemanusiaan, fakta sosial, penstrukturan dan pandangan dunia. Fakta kemanusiaan melihat manusia mengalami proses penstrukturan secara terus-menerus ketika bertemu dengan lingkungan masyarakat yang ada di sekelilingnya, sehingga membentuk pandangan dunia yang bulat dan utuh, hasil observasi sastrawan atas dunia yang ada di sekelilingnya, realitas 
sosial yang konkret terbentuk lama. Sehingga dapat dikatakan bahwa karya sastra merupakan struktur bermakna yang mewakili pandangan dunia pengarang sebagai representasi dari kelompok masyarakatnya (Goldman dalam Farhah, 2015:21).

Teori ini merupakan teori yang menganggap bahwa karya sastra tidak bersifat statis. Akan tetapi karya sastra adalah struktur yang terbentuk dari subjek pencipta karya dengan situasi sosial atau subjek kolektif. Menurut Fernando, Goldman menyusun penelitian ini dalam tiga langkah, yaitu : (1) Penelitian dimulai dari kajian unsur intrinsik sebagai data dasarnya. Data tersebut kemudian dihubungkan dengan berbagai unsur dan realitas masyarakat, karena karya sastra adalah refleksi zaman yang mengungkapkan unsur-unsur ekstrinsik pembentuk teks seperti aspek sosial, politik, budaya, ekonomi dan lain-lain. (2) Kajian atas kehidupan sosial budaya pengarang, karena sastra merupakan cerminan keadaan sosial pengarang, baik secara individual maupun kolektif. (3) Kajian atas latar belakang sosial sejarah (Fernando dkk, 2018:74).

Adapun pandangan dunia atau world view adalah sudut pandang pengarang yang disusun dari aspek dasar, yaitu pengarang, teks sastra dan pembaca. Apa yang disusun pengarang merupakan refleksi pantulan fenomena sosial yang dideskripsikan dalam kata-kata (Farhah, 2015:27-28). Struktur karya sastra sendiri bersifat homolog atau sejajar dengan pandangan dunia pengarang yang hidup dan tinggal di dalam masyarakat di mana karya sastra tersebut dilahirkan. Menurut Al-Jayyar (dalam Farhah, 2015:29-30), untuk mewujudkan homologi antara keduanya, yang tersirat dan tersurat dibutuhkan bantuan strukturalisme genetik. Sementara pandangan dunia sendiri tidak statis, dan bukan fakta, namun hanya ekspresi teoretis dari kondisi dan kepentingan suatu golongan masyarakat tertentu, yang menurut Goldman untuk menjembatani fakta estetik. Fakta estetik ini dibagi menjadi menjadi dua tataran hubungan yang meliputi: (1) Hubungan antara pandangan dunia sebagai suatu realitas yang dialami dengan alam ciptaan pengarang, dan (2) Hubungan alam ciptaan pengarang dengan alat sastra tertentu, seperti diksi, sintaksis, plot, dan gaya bahasa yang merupakan hubungan struktur cerita yang dipergunakan pengarang dalam ciptaannya (Fernando, dkk, 2018:75).

Penelitian ini menggunakan pendekatan kualitatif yang bersifat deskriptif. Adapun sumber data dalam penelitian ini terdiri atas sumber data primer yang diambil dari novel Sumayyah karya Abadzah dan sumber data sekunder yang didapatkan dari artikel, berita koran, majalah, blog, internet, buku, dan lain-lain dengan teknik baca dan catat.

\section{Pembahasan}

Tokoh Marruni dalam novel Sumayyah ini dipilih sebagai objek formal karena karena beberapa hal, yaitu : (1) Marruni adalah buruh migran Indonesia yang bekerja menjadi pembantu di Timur Tengah; (2) kisah buruh migran Indonesia yang bekerja masih jarang diangkat dalam novel-novel berbahasa Arab; (3) tokoh Marruni dalam novel Sumayyah ini adalah tokoh yang dibuat dari sudut pandang penduduk negara pengguna jasa buruh migran; (4) konflik Marruni adalah konflik psikologis yang kemudian berubah menjadi konflik sosial. Hidup di negara asing selama bertahun-tahun, jauh dari keluarga dan berada di antara orang yang hanya menjadikannya sebagai alat dan bukan manusia akan menimbulkan rasa sepi dan terasing. Permasalahan psikologis Marruni ini dia selesaikan dengan menjalin hubungan terlarang dengan lakilaki yang bukan suaminya, sehingga kemudian menjadi masalah sosial bagi keluarga majikannya.

Marruni adalah pembantu berkebangsaan Indonesia yang memutuskan untuk bekerja di Syria karena sedikitnya lapangan pekerjaan di Indonesia. Marruni digambarkan memiliki latar belakang keluarga yang miskin, sehingga harus bekerja keras hingga ke luar negeri meskipun sesungguhnya kondisinya belum memungkinkan untuk 
bekerja jauh dari keluarnya, karena baru saja melahirkan.

$$
\begin{aligned}
& \text { وقبل أن ندخل الغرفة صادفنا مرووني } \\
& \text { الإندونيسية خادمة أمي }
\end{aligned}
$$

Sebelum masuk kamar, kami bertemu dengan Marruni orang Indonesia, pembantu ibuku (Abadzah, 2009:19).

وكنت أحزن لمروي أحيانا إذا إنا أم لطفلة

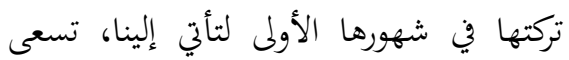

وراء لقمة العيش، فتكسب دولارات

معدودات تقنع بها. ترسلها إلى أهلها كل

بضعة أشهر. أهل ينتظرون. يعانون الفقر.

يعيشون على حفنات أرز، وبقية من لحم

الدجاج عند المناسبات. قصار القامة.

نحيلون. فطس الأنوف. لوحتهم الشمس الشسبات

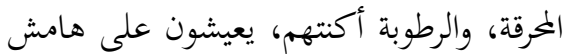

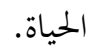

Terkadang aku sedih dengan apa yang terjadi kepada Marruni. Dia adalah seorang ibu yang meninggalkan anaknya yang masih berusia beberapa bulan hanya untuk bekerja kepada kami. Meninggalkan anaknya demi suapan kehidupan. Demi beberapa lembar dolar saja, dia menerima itu. Dolar tak seberapa itu akan dia kirim untuk keluarganya dalam beberapa bulan. Apakah mereka menunggu kiriman itu? Untuk menghalau kemiskinan mereka? Mereka yang hidup hanya dengan beberapa genggam beras. Dengan sisa-sisa daging ayam yang hanya akan mereka makan setiap kali ada acara saja. Orang-orang dengan perawakan pendek, kurus, dengan hidung pesek. Warna kulit yang terbakar matahari, dengan tutup yang lembab, mereka hidup sebagai masyarakat yang terpinggirkan (Abadzah, 2009:99).

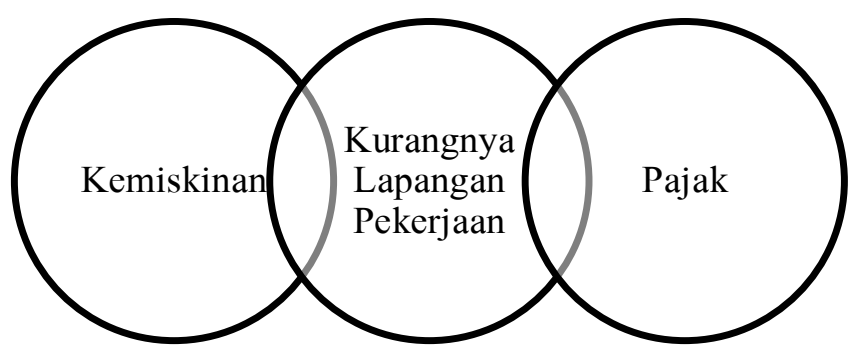

Diagram 1: Alasan Indonesia mengirimkan tenaga kerjanya ke Luar Negeri

Meski gaji yang diterima sedikit, namun gaji tersebut sangat berharga, bukan hanya untuk keluarganya, akan tetapi juga untuk negara dan kantor PJTKI. Akan tetapi keberangkatannya ke Syria hanya bermodalkan semangat bekerja, tanpa bekal wawasan akan pekerjaan yang akan dia lakukan nantinya, atau bahasa yang akan dia gunakan untuk berkomunikasi di negara tujuan. Kedua hal inilah sumber masalah utama para buruh migran, meskipun sebelum berangkat bekerja ke negara tujuan mereka sudah belajar bahasa dan keterampilan kerja. Kedua masalah tersebut membuat wajah Marruni tampak bodoh dengan tatapan kosong dan tidak berani melakukan apapun tanpa adanya perintah dari majikannya, sehingga tampak seperti satpam tua yang menunggu di pos jaga. Penampilan fisiknya pun tidak kalah buruknya, gadis muda dengan dandanan sederhana, tubuh yang kurus dan pendek serta kulit yang coklat kehitaman karena terbakar matahari. 


$$
\begin{aligned}
& \text { كانت مروني في العشرينات. دخلت بيتنا منذ } \\
& \text { سنتين تقريبا. لم تكن تفهم من العربية كلمة. }
\end{aligned}
$$

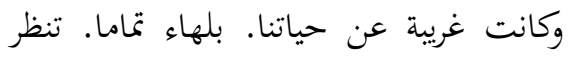

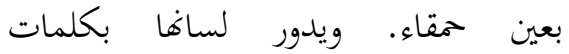

$$
\begin{aligned}
& \text { عجماء.... وعلمتها أمي أبجدية الطبخ } \\
& \text { وتنظيف البيت. }
\end{aligned}
$$

Saat itu Maruni berusia 20an. Dia masuk ke rumah kami dua tahun lalu. Dia tak mengerti bahasa Arab sedikitpun. Dia pun tak memahami kehidupan kami. Sangat asing. Sangat bodoh. Menatap dengan tatapan anak bodoh. Sementara lidahnya mengucapkan kata-kata aneh. Ibuku mengajarinya abcd memasak dan membersihkan rumah (Abadzah, 2009: 98).

$$
\text { وقبل أن ندخل الغرفة صادفنا مروين }
$$

$$
\begin{aligned}
& \text { النحيلة، وبشرتا السمراء الداكنة، تقف } \\
& \text { كالبلهاء في إحدى الزوايا، لا تدري ماذا }
\end{aligned}
$$

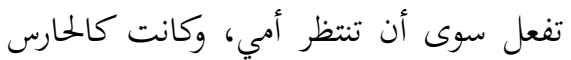

$$
\begin{aligned}
& \text { العجوز الذي لم يعد يعرف من الحراسة سوى }
\end{aligned}
$$

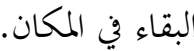

Sebelum masuk kamar, kami bertemu dengan Marruni yang pembantu ibuku, warga negara Indonesia. Perempuan dengan perawakan pendek kurus, dengan kulit coklat gelap. Gadis itu berdiri seperti orang bodoh di salah satu sudut rumah sakit, tidak tahu apa yang harus dia lakukan selain menunggu Ibuku. Seperti penjaga keamanan tua yang tak tahu lagi bagaimana cara menjaga yang sesungguhnya selain menetap dan tinggal di pos jaga (Abadzah, 2009: 27).

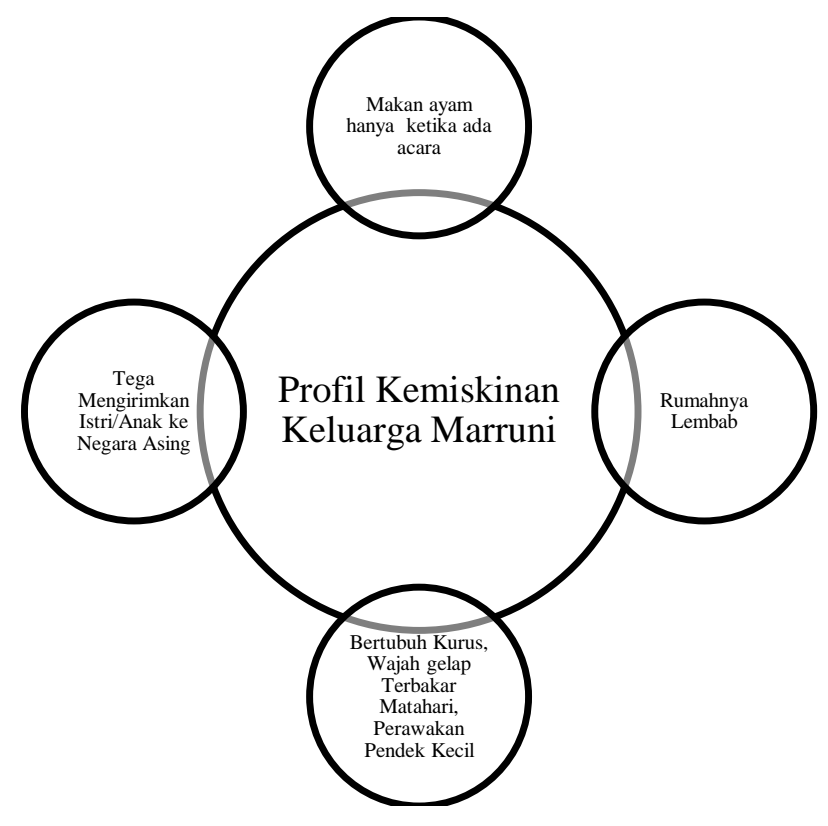

Diagram 2: Profil Kemiskinan keluarga Marruni

Akan tetapi keluarga Sumayyah sangat terbantu dengan keberadaan Marruni, bahkan keluarga ini lebih menyukai Marruni, pembantu Indonesia dari semua pembantu-pembantu lainnya.

$$
\text { تم جرب بيتنا التعامل مع الشغالات اللواتي }
$$




$$
\begin{aligned}
& \text { لم تكن إحداهن تستمر بين يدي أمي سوى } \\
& \text { شهور تسأم منها، ثم تترك العمل، لتبحث } \\
& \text { الأسرة عن امرأة جديدة. }
\end{aligned}
$$

Rumah kami kemudian mencoba untuk berinteraksi dengan berbagai pekerja yang menamakan diri sebagai Rabbatal Buyut (Lufayat) yang datang pada pagi hari, dan pulang pada sore hari, setelah selesai melakukan semua yang harus dia lakukan di rumah ini.

Namun tak ada satu pun dari mereka yang tahan untuk melayani ibuku, jika pun bertahan, mereka hanya tahan selama beberapa bulan saja. Kemudian merasa putus asa dan meninggalkan rumah untuk mencari keluarga lain. Keluarga ini kemudian mencari pembantu baru yang lain (Abadzah, 2009: 102103).

Marruni adalah sosok pembantu yang memenuhi harapan majikannya, sehingga mampu bertahan untuk bekerja di rumah Sumayyah antara dua hingga tiga tahun. Hal tersebut disebabkan oleh beberapa karakter Marruni sebagai sosok yang sabar, pasrah, mau belajar dan tekun dalam menjalankan tugas-tugasnya. Sikap-sikap ini membuatnya mampu melewati masa-masa sulit saat harus beradaptasi dengan kendala komunikasi, pengetahuan dan budaya Syria, sehingga Marruni kemudian mampu berinteraksi dengan baik dengan seluruh anggota keluarga majikannya, terutama majikan perempuannya yang digambarkan memiliki kepribadian yang sulit. Di samping itu Marruni mampu menjalankan tugasnya dengan baik sebagaimana yang diinginkan oleh majikannya. Kemauannya untuk belajar dan menjalankan tugas ini yang kemudian membuat Marruni mendapatkan pengakuan dan kepercayaan penuh dari majikannya.

$$
\text { فتعلمت يوماكها أمي أبجدية الطبخ وتنظيف البيت. }
$$

$$
\begin{aligned}
& \text { وتعيد كلماتما كالبغاء الثرثارة... وصارت } \\
& \text { تتكلم مثلنا. ولكن بلكنة مشينة.... وتفهم } \\
& \text { كل كلمة وهمة وإثارة. }
\end{aligned}
$$

Maka Marruni pun belajar sedikit dari Ibuku demi sedikit setiap hari. Hinggga kemudian menjadi mahir. Dia menirukan semua tingkah Ibuku bagaikan monyet tua. Mengulang tiap kata-kata Ibuku bagai burung beo berisik. Sehingga bisa berbicara dan berkomunikasi seperti kami, namun dengan logat yang jelek. Maka dia pun memahami dan mengerti semua kata, sетиa bisikan dan sетиа isyarat (Abadzah, 2009: 98).

$$
\begin{aligned}
& \text { كانت تعاملها غالبا بالإحسان، ولو أها } \\
& \text { تعنف عليها في مرات كثيرة، وتسبها، وترفع } \\
& \text { عليها صوت وربما قم بضربها. ومروني تتقبل }
\end{aligned}
$$

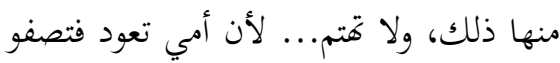

$$
\begin{aligned}
& \text { معها. ولأن البنت تتحمل طلباتا الثقيلة } \\
& \text { كدمها، لحاجتها إلى العمل. } \\
& \text { ولعل مروني قم سوقيتها مثلها، فلذلك ترضى الكى } \\
& \text { بكل ما تفعل. } \\
& \text { وكانت أمي تمدح مروين كثيرا على الملأ، } \\
& \text { وتشيد بمهارتا في العمل، وكانت مروني من } \\
& \text { طرفها تفرح بذلك المديح }
\end{aligned}
$$

Sebenarnya Ibuku memperlakukan Marruni dengan baik, meskipun berulang kali bersikap kasar kepadanya, mendorongnya, meneriakinya, atau bahkan mungkin memukulnya. Marruni menerima semua itu dan menahan diri untuk tidak melakukan apapun ketika menghadapi perlakukan tidak pantas dari ibuku itu. Karena Ibuku kemudian akan kembali bersikap baik kepadanya seakan tak ada apapun yang terjadi antara mereka, mungkin juga karena gadis itu sabar dengan tuntutan Ibuku yang berat seperti orangnya, 
Marruni sabar dengan perlakuan Ibuku karena sangat membutuhkan pekerjaan ini.

Bisa jadi karena Marruni samasama kampungannya dengan Ibuku. Sehingga bisa mengerti dan mau memahami apapun yang ibuku lakukan kepadanya.

Ibuku sering memuji Marruni tanpa alasan jelas, memuji kemampuan kerja Marruni, sementara Marruni sendiri gembira menerima pujianpujian Ibuku itu (Abadzah, 2009: 98).

Adapun alur kehidupan yang dilalui Marruni dalam kehidupannya sebagai Buruh Migran di rumah keluarga Sumayyah adalah sebagai berikut: (1) Marruni datang ke Syria dalam usia 20an tahun tanpa bekal pengetahuan dan bahasa Arab.

$$
\begin{aligned}
& \text { كانت مروين في العشرينات. دخلت بيتنا منذ } \\
& \text { سنتين تقريبا. لم تكن تفهم من العربية كلمة. } \\
& \text { وكانت غريبة عن حياتنا. بلهاء تماما. تنظر }
\end{aligned}
$$

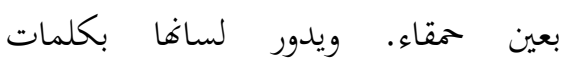

$$
\begin{aligned}
& \text { عجماء.... }
\end{aligned}
$$

Maruni berusia 20an. Masuk ke rumah kami dua tahun lalu. Dia tak mengerti bahasa Arab sedikitpun. Dia pun tak memahami kehidupan kami. Sangat asing. Sangat bodoh. Menatap dengan tatapan anak bodoh. Sementara lidahnya mengucapkan kata-kata aneh (Abadzah, 2009: 98).

(2) Marruni berusaha menjadi pembantu yang baik dengan melakukan semua yang diperintahkan majikannya dengan sebaikbaiknya serta berusaha memahami apa yang disampaikan oleh majikannya, sehingga mampu memahami bahasa Arab dalam dua hingga tiga tahun saja. Sikap yang diambil Marruni ketika menerima kemarahan majikannya yang temperamental adalah diam dan bersabar. Sikap inilah yang membuatnya semakin mendapatkan tempat di hati majikannya hingga kemudian memberikan pujian kepadanya. Pujian dan kepercayaan ini membuat Marruni gembira.

$$
\text { وكانت أمي تمدح مروني كثيرا على الملأ، }
$$

Ibuku sering memuji Marruni tanpa alasan jelas, memuji kemampuan kerja Marruni, sementara Marruni sendiri gembira menerima pujianpujian Ibuku itu (Abadzah, 2009: 98).

$$
\begin{aligned}
& \text { أعود إلى الحادث الغريب الذي تسببت به } \\
& \text { مروني الإندونيسية، وقد كنت من قبل أشعر }
\end{aligned}
$$

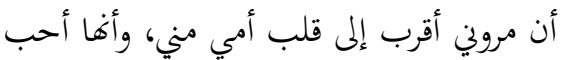

$$
\begin{aligned}
& \text { إليها. }
\end{aligned}
$$

Aku teringat akan kejadian aneh yang disebabkan oleh Maruni pembantu Indonesia itu. Sejak awal aku sudah merasa bahwa Marruni bisa lebih dekat dengan Ibuku daripada aku. Sepertinya Ibuku lebih mencintai Maruni daripada aku (Abadzah, 2009: 97).

(3) Penerimaan dan pujian itu membuat kedudukan Marruni Istimewa di mata majikannya. Marruni menjadi orang kepercayaan majikannya dan menjadi pelengkap kehidupan keluarga sang majikan.

$$
\begin{aligned}
& \text { وغدت مرين مع الأيام قطعة من بيتنا. وجزءا } \\
& \text { مكملا من لوحة أمي الجدارية. أو نغمة ميزة } \\
& \text { من معزوفتها الموسيقية. }
\end{aligned}
$$

Seiring berjalannya waktu, Marruni menjadi bagian dari rumah kami, menjadi bagian penyempurna hiasan dinding Ibuku, atau denting istimewa dari irama musik ibuku (Abadzah, 2009: 98).

(4) Sikap majikan Marruni yang menganggapnya sebagai orang yang dapat dipercaya, dan kesabaran serta ketekunan Marruni membuatnya hafal 
akan kebiasaan seluruh anggota keluarga majikannya tersebut. Marruni mengetahui dengan baik seluruh selukbeluk rumah Sumayyah.

$$
\text { تعرف حركاتنا كلها بدقة، أبيت كثت تصرف مروبي التي }
$$

Rumah dan seisinya berada dalam kendali Marruni. Dia mengetahui gerak-gerik kami dengan detail. Lebih banyak dari yang kami ketahui (Abadzah, 2009: 101).

(5) Setelah dua hingga tahun bekerja, majikannya merasakan hal yang mencurigakan dari diri Marruni

$$
\begin{aligned}
& \text { أحست أمي فجأة بشيء غير طبيعي. }
\end{aligned}
$$

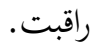

$$
\begin{aligned}
& \text { كانت البيت كله تحت تصرف مروني التي } \\
& \text { تعرف حركاتنا كلها بدقة، أكثر مما نعرفها } \\
& \text { نحن. }
\end{aligned}
$$

Ibu merasakan sesuatu yang tidak biasa.

Dia mengamati

Rumah dan seisinya berada dalam kendali Marruni. Dia mengetahui gerak-gerik kami dengan detail. Lebih banyak dari yang kami ketahui (Abadzah, 2009: 101).]

(6) Perbedaan sikap Marruni adalah karena berselingkuh dengan laki-laki Bangladesh yang bukan suaminya. Marruni ketahuan tengah melakukan hubungan terlarang dengan laki-laki Bangladesh tersebut di dalam rumah majikannya.

$$
\begin{aligned}
& \text { وفي مرة من المرات عادت إلى بيتها بعد ما } \\
& \text { نسيت حاجة لها استلزمت عودةقا. } \\
& \text { فوجدت رجلا عندنا......... } \\
& \text { وكانت مروني معه في وضع فاضح جدا. } \\
& \text { لم يكن أحد منا يتصور ذلك. }
\end{aligned}
$$

Suatu kali, Ibu pulang lagi dalam beberapa menit kepergiannya keluar rumah. Ketika melupakan sesuatu yang penting dan memaksanya untuk mengambil apa yang dia lupakan.

Kemudian Ibu menemukan ada lakilaki di dalam rumah kami Marruni sedang bersamanya dalam situasi yang sangat memalukan. Tak ada satu orang pun dari kami yang pernah membayangkan hal itu (Abadzah, 2009: 101).

(7) Marruni mendapatkan cacian dan hinaan dari majikannya yang menganggap apa yang dilakukan oleh Marruni adalah kesalahan besar yang tidak dapat dimaafkan.

$$
\text { صرخت أمي صرخات فظيعة، ولاذ الرجل }
$$

Ibuku berteriak kesetanan. Laki-laki itupun melarikan diri setelah menyahut pakaiannya dengan cepat (Abadzah, 2009: 101).

(8) Syria adalah negara yang kental dengan nilai-nilai Islam, sehingga perbuatan Marruni tersebut telah menciptakan aib bagi keluarga majikannya.

$$
\text { وضعا تماما مروذا ستفعل؟ الأسرة في بحربة جديدة، لم تدر }
$$

Marruni telah menyeret keluarga ini ke dalam sebuah pengalaman baru yang belum pernah dia miliki sebelumnya, sehingga keluarga tidak tahu apa yang harus dia lakukan kepada Marruni? (Abadzah, 2009: 101).

(9) Marruni diusir dan dikembalikan ke kantor PJTKI di Syria setelah sebelumnya dicaci-maki oleh majikannya. 


$$
\begin{aligned}
& \text { صحبت أمي مروني إلى مكتب الاستخدام } \\
& \text { أخيرا. . وغادرةما وهي هناكئ مروي إل.... تلعنها، } \\
& \text { وتسبها بكل ما أمكن لها من شتائم. } \\
& \text { وانسدل الستار على مسرحية مروين. }
\end{aligned}
$$

Akhirnya Ibuku membawa Marruni ke kantor perwakilan tenaga kerja. Kemudian meninggalkan Marruni di sana. Di kantor itu, Ibu melaknatnya, mencelanya dengan semua celaan yang bisa dia sampaikan (Abadzah, 2009: 104).

(10) Sumayyah mengakui kecerdasan dan kepandaian Marruni dan merasa tertipu dengan sikap lugu dan sederhana Marruni.

$$
\begin{aligned}
& \text { لم يكن يتصور أحد منا أن البنت تخفي وراء } \\
& \text { هدوئها مكرا مبيتا، ينطلي علينا كلنا... }
\end{aligned}
$$

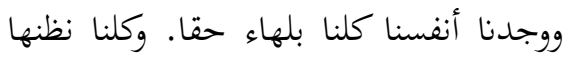

$$
\begin{aligned}
& \text { البلهاء الوحيدة. }
\end{aligned}
$$

Tak ada satupun dari kami yang pernah membayangkan bahwa gadis ini di belakang ketenangannya menyembunyikan sebuah rencana tersembunyi. Menyembunyikan sesuatu yang kami tak perhatian semua itu. Lalu kami menyadari diri bahwa kami selama ini sangat bodoh. Sementara kami menganggap dialah satu-satunya yang bodoh yang ada di dalam rumah ini (Abadzah, 2009: 101).

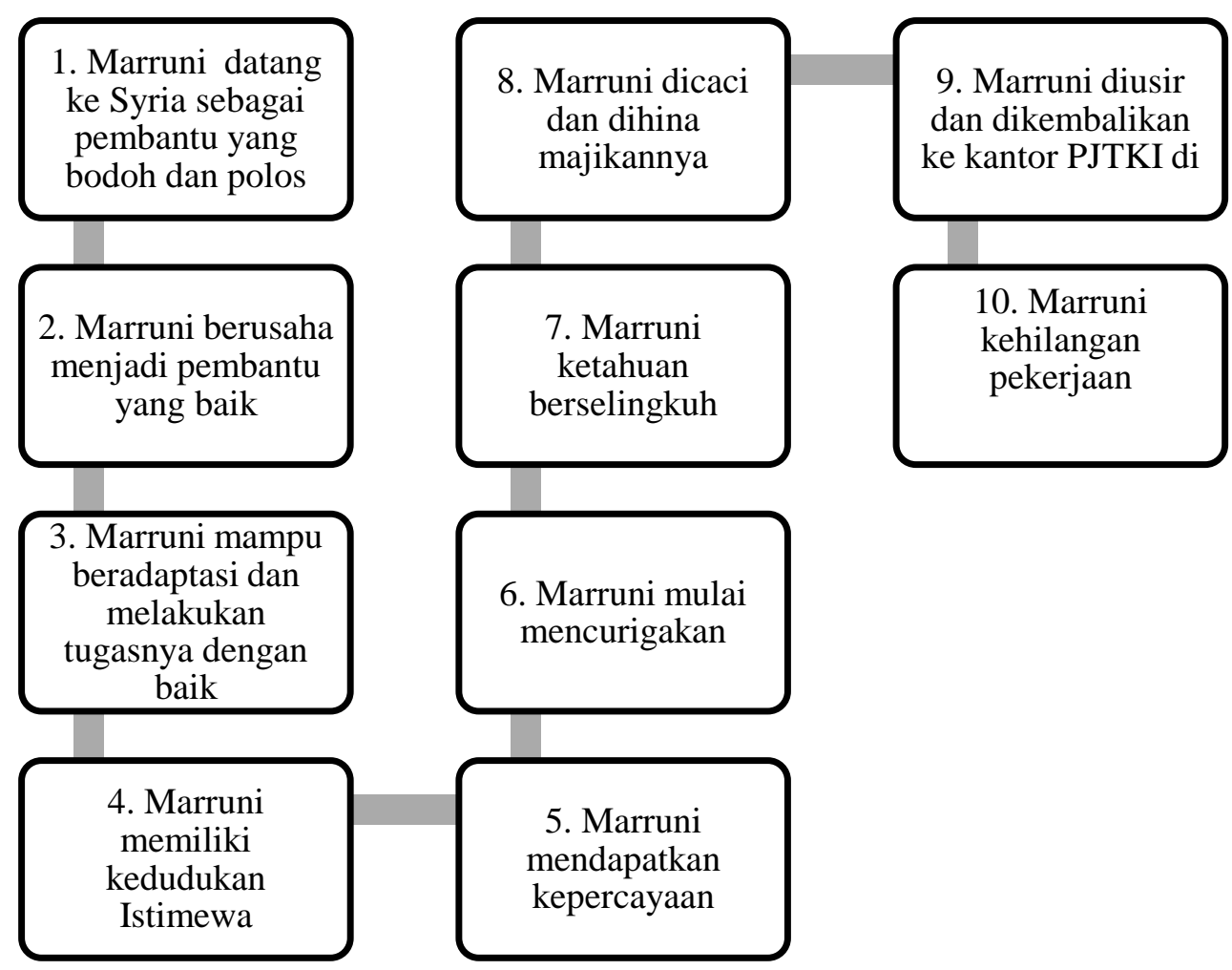

Diagram 3: Alur Perjalanan Marruni sebagai Buruh Migran

Sebagai buruh migran, Marruni tidak memiliki kekuatan untuk membela dirinya. Kesabaran dan apa yang sudah Marruni lakukan selama bekerja menjadi tidak berarti karena kesalahan yang dia lakukan. 


$$
\begin{aligned}
& \text { وتساءلت: ما شعورهن؟ بم يفكرون؟ وكيف } \\
& \text { يفكرن؟ ماذا وراء الصمت الذين يتحلين به؟ } \\
& \text { وما تصنع هذه الدولارات القليلة؟ التي تصل } \\
& \text { إليهم...... وأكثر منها يصل إلى أيدي } \\
& \text { أصحاب المكاتب، وضريبة للدولة؟ } \\
& \text { ثلاث سنوات تمضي إحداهن هنا..... فإذا } \\
& \text { عادت فكيف ستجد الحياة هناك؟ }
\end{aligned}
$$

Aku bertanya-tanya: Bagaimana perasaan para gadis ini? apa yang keluarganya pikirkan? Bagaimana mereka memikirkan anak-anak perempuan ini? apa yang ada di belakang kebisuan yangpara gadis ini kenakan? Apa yang bisa dilakukan oleh sedikit lembaran dolar yang mereka terima setiap bulannya? Yang kemudian hanya akan sampai untuk mereka yang di negaranya? Sementara sebagian besar lembar-lembar dolar itu hanya akan sampai ke para pemilik kantor pjtki, atau sebagai pajak Negara?

Salah satu dari para gadis ini menghabiskan hari-harinya selama tiga tahun di sini. Lalu bagaimana jika memutuskan untuk pulang, kehidupan apa yang akan dia temukan di sana? (Abadzah, 2009:99)

Pengarang melihat Buruh Migran sebagai sosok kasihan yang bekerja keras demi semua orang, baik keluarga, negara, PJTKI maupun majikannya di negara di mana dia bekerja. mereka harus kehilangan diri, waktu, tenaga, usia dan kenangan bersama keluarga untuk tinggal di luar negeri bersama orang asing. Di samping itu, keberadaan para Buruh Migran pun telah tercerabut dari lingkungan sosialnya, baik di Indonesia maupun di negara di mana dia bekerja. Sebagai makhluk sosial, permasalahan tersebut kemudian menghadirkan permasalahan psikologis seperti rasa sepi, sendiri dan kerinduannya yang mendalam kepada keluarga. Ada berbagai cara yang ditempuh oleh para pekerja migran untuk menyelesaikan permasalahan individual ini, namun Marruni memilih untuk menyelesaikannya dengan menjalin hubungan dengan laki-laki Bangladesh. Begitu pun dengan tempat tinggal yang dia kuasai selama bekerja, sesungguhnya itu bukanlah rumahnya.

\section{Kesimpulan}

Abadzah melihat Marruni sebagai tokoh yang miskin luar dalam dan membutuhkan belas kasihan. Marruni tidak memiliki hak atas dirinya, baik sebagai individu maupun makhluk sosial. Marruni bekerja untuk semua orang, baik keluarga, negara atau perusahaan pengirimnya, akan tetapi tidak ada satu orangpun yang mendukung, dan menguatkannya. Semua usaha yang dia lakukan hanya seperti istana dari pasir, yang menunggu waktu untuk hancur. Sebuah kesalahan yang tidak berhubungan dengan pekerjaanpun, mampu membuatnya kehilangan semua usaha baik yang dia lakukan selama bertahun-tahun. Sehingga pemerintah harus melakukan kajian terusmenerus akan bentuk kerja sama penempatan para buruh migran ini yang menjamin hak-hak mereka sebagai individu yang berharga dan haknya untuk berinteraksi sosial. Buruh migran adalah manusia yang memiliki hak dan kewajiban yang sama dengan penduduk Indonesia lainnya, yang harus dijaga hak hidup dan hak sosialnya. Adapun upah para Buruh Migran, dapat dilihat dari dua sudut pandang. Upah ini nampak kecil bagi negara tujuan dan besar bagi para buruh migran. Kedua sudut pandang ini memberikan implikasi yang berbeda bagi keduanya. Para buruh migran ini akan bekerja sekuat tenaga, karena merasa upahnya besar, dan dia membutuhkan pekerjaan ini. Akan tetapi di sisi lain, upah ini nampak murah bagi negara tujuan, sehingga mereka berlomba-lomba menggunakan jasa para buruh migran, yang berimbas pada sikap para majikan yang sewenang-wenang dalam memperlakukan sang buruh migran sebagaimana yang mereka inginkan. 


\section{Daftar Pustaka}

Abadzah, Nizar. 2009. Sumayyah. Damaskus: Darul-Fikr.

Abdullah I. 2001. Seks, Gender \& Reproduksi Kekuasaan. Yogyakarta: Tarawan Press.

Azmy, Ana Sabhana. 2012. Negara dan Buruh Migran Perempuan: Menelaah Kebijakan Perlindungan Masa Pemerintahan Susilo Bambang Yudhoyono 20042010. Jakarta: Pustaka Obor.

Bandiono, Suko dan Alihar Fajri. 1999. Tinjauan Penelitian Migrasi Internasional di Indonesia dalam Globalisasi dan Migrasi antar Negara. Bandung: Alumni.

Farhah, Eva. 2015. Romantisisme Islam, Analisis Strukturalisme Genetik dalam Thauqul-Chamamah Fil Ilf Wal-Ullaf Karya Ibnu Chazm AlAndalusy. Disertasi Program Studi Agama dan Lintas Budaya Minat Kajian Timur Tengah (Sastra Arab) Universitas Gadjah Mada Yogyakarta.

Faruk. 2012. Pengantar Sosiologi Sastra. Yogyakarta: Pustaka Pelajar.

Fernando, Victhor; Mulawarman Widyatmike Gede; Rokhmansyah Alfian. 2018. Pandangan Dunia Pengarang Dalam Novel Mellow Yellow Drama Karya Audrey Yu Jia Hui: Kajian Strukturalisme Genetik. Jurnal Ilmu Budaya, 2(1), 71-80.

Goldmann, Lucien. 1967. The Sociology of Literature: Status and Problem of Method. International Social Science Journal: Sociology of Literary Creativity, 19(4), 493518.

Hakim, Lutpiyah. 2013. Pandangan Dunia Ali Ahmad Bakatsir dalam Novel Sallamah Al-Qas analisis Strukturalisme Genetik Lucien Goldmann. Tesis Sastra Universitas Gadjah Mada Yogyakarta.
Hidayah, Anis dkk. 2013. Selusur Kebijakan Minus Perlindungan Buruh Migran Indonesia. Jakarta: Migrant CARE

Irawaty T. 2011. Migrasi Internasional Perempuan desa dan pemanfaatan Remitan di desa Pusakajaya, kecamatan Pusakajaya, Kabupaten Subang, Provinsi Jawa Barat. Skripsi. Institut Pertanian Bogor.

Nainggolan, Togiaratun. 2008. Gender dan Keluarga Migran di Indonesia. Jurnal Penelitian dan Pengembangan Kesejahteraan Sosial, 13(3), 39-50.

Nasution, M Arif. 1998. Mobilitas Tenaga Kerja Indonesia ke Luar Negeri dan Dampaknya Terhadap Diri Migran. Suatu Tinjauan Awal Terhadap Kasus Buruh Bangunan di Kuala Lumpur. Jurnal Populasi, 9(2), 59-77.

Novitasari, Lilis. 2017. Faktor Pendorong Moratorium Pengiriman TKI Ke Arab Saudi Era Susilo Bambang Yudhoyono (2009-2014). Skripsi Program Studi Hubungan Internasional Fakultas Ilmu Sosial Politik Universitas Wahid Hasyim.

Nurgiyantoro, Burhan. 2013. Teori Pengkajian Fiksi. Yogyakarta: Gadjah Mada University Press.

Raharto, Irma Selly. 2011. The migration experience of returned Migrant Domestic Workess: the example of Indonesia. Makalah disajikan dalam dialog antara negara-negara ESCWA dan SCAP pada Migrasi dan Pembangunan Internasional. Beirut, 28-30 juni 2011.

Rohmah, Babun Ni'matur dan Sari, Riska Ayu P. 2017. Tingkat Perubahan Kesejahteraan Ekonomi Keluarga Buruh Migran di Desa Panggungrejo Gondanglegi Malang. Jurnal Intaj, (1), 120144. 
Sangidu. 2004. Penelitian Sastra: Pendekatan, Teori, Metode, Teknik dan Kiat. Yogyakarta: Unit Penerbitan Sastra Asia Barat Universitas Gadjah Mada

Santosa, Puji. 2006. Pandangan Dunia Darmanto Jatman. Jakarta: Pusat Bahasa Departemen Pendidikan Nasional.

Soelaiman, T. 2002. Solusi Upaya Perlindungan Tenaga Kerja Indonesia (TKI) Luar negeri. Jurnal Hukum dan Pembangunan, 32(3), 295-302.

Sulistiyo, Putri Asih dan Wahyuni, Ekawati sri. 2012. Dampak Remitan Ekonomi terhadap Posisi Sosial Buruh Migran Perempuan dalam Rumah Tangga. Jurnal Solidarity, 6(3), 252-258.

Susilowati, Indah; Mudji Rahardjo; Waridin. 2001. Analisis Masalah Sosial, Politik dan Ekonomi Pada Migrasi Tenaga Kerja Indonesia Ke Luar Negeri. Laporan Penelitian DCRG (Domestic Collaborative Research Grant) Dirjen Dikti Departemen Pendiikan Nasional 2000/2001.

Toyib, Muhammad. 2009. Perspektif Hukum Islam Terhadap Relasi Perjanjian Kerja Buruh Migran Indonesia dengan Perlindungan Atas Hak-hak Keluarganya: Studi Analisis Terhadap Pasal 55 UU No.39 Tahun 2004 Tentang PPTKLN. Skripsi. UIN Sunan Ampel.

Wafirotin, Khusnatul Zulfa dkk. 2013. Dampak Migrasi terhadap Kondisi Sosial Ekonomi Keluarga TKI di Kecamatan Babadan Kabupaten Ponorogo. Jurnal Ekulobrium, 11(2), 15-33.

Wulan, TR. 2010. Pengetahuan dan Kekuasaa: Penguatan Remitten Sosial sebagai strategi Pemberdayaan Migran
Perempuan. (disertasi). Institut Pertanian Bogor.

Astuti, TMP. 2008. Migrasi Internasional dan Posisi Sosiokultural Perempuan dalam Masyarakat (Kasus TKW Gadog, Grobogan ke Malaysia dan Singapura) Dalam: Studi Pembangunan Interdisipliner (Internet). Diunduh dari:

http://isjd.pdii.lipi.go.id/admin/jur nal/2220887103.pdf

Bakr, Abdul-Aziz. www.lahaonline.com. Diakses pada 25 Desember 2018. Jam 17.36

Nugraha, Rizki. M.dw.com. Diakses pada 8 April 2018. Jam 13.29.

Praditya, Ilyas Istianur Liputan6.com. Diakses pada 8 April 2018

Kompas 9 April 2000. Kartini, TKW Purwakarta Diancam Hukuman Rajam Sampai Mati Karena Hamil di Luar Nikah Akibat Hubungan Gelap Sesama Pekerja Asing di Kota Fujairan Uni Emirat Arab.

Kompas: 19 juni 2000. Timur Tengah Tidak Lagi Menjadi Surga Keberuntungan, Bisa Berubah Menjadi Mimpi Buruk dan Kemalangan bagi Sebagian TKI.

Lahaonline.com. أنا مشغوف بالوجوه الدمشقية. Diakses tanggal 12 Oktober 2019. Jam 6.22.

paltoday.ps/ar/post/54532/ خادمة إندونبيسية Diakses pada 10 Oktober 20219 jam 20.45

zamanalwsl.net. مينة مستحثثة تغزو البيوت السورية الخادمات قادمات.. والسوق عاوز كده Diakses pada 10 oktober 2019. Jam 20.46.

Wahyuni, Nurseffu Dwi Liputan6.com. Diakses pada 8 April 2018

www.bbc.com. Pengiriman pekerja Indonesia ke Suriah masih berlangsung meski sudah dilarang dan perang berkobar. Diakses 
tanggal 10 oktober 2019. Jam 19.45 .

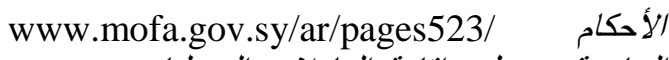
الخاصة بلخول وإقامة العاملات المنزليات Diakses pada 30 september jam. 17.00.

www.buruhmigran.or.id. Wahyudi, Ridwan. 2015. Mengenal Teoriteori Migrasi Pekerja
Internasional. diakses pada 7 Nopember 2019. Jam 03.06.

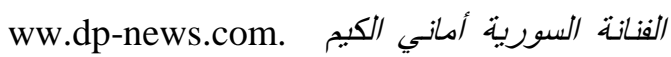

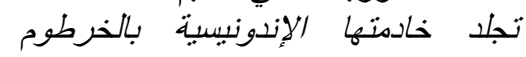
diakses pada 1 oktober 2019. Jam 01.11.am

www.resmipjtki.com. Persyaratan TKI/TKW Indonesia. Diakses pada 9 Nopember 2019. Jam 10.05 . 